\title{
Caring Wisely: A Program to Support Frontline Clinicians and Staff in Improving Healthcare Delivery and Reducing Costs
}

\author{
Ralph Gonzales, MD, MSPH ${ }^{1,5^{*}}$, Christopher Moriates, MD², Catherine Y Lau, MD³ , Victoria Valencia, MPH², Sarah Imershein, \\ $\mathrm{MS}^{4}$, Alvin Rajkomar, $\mathrm{MD}^{3}$, Priya Prasad, $\mathrm{PhD}^{5}$, Christy Boscardin, PhD¹, Deborah Grady, MD ${ }^{1,6}$, S. Claiborne Johnston, MD, PhD \\ ${ }^{1}$ Department of Medicine, Division of General Internal Medicine, University of California, San Francisco; ${ }^{2}$ Department of Internal Medicine, Dell \\ Medical School at The University of Texas at Austin, Texas; ${ }^{3}$ Department of Medicine, Division of Hospital Medicine, University of California, San \\ Francisco; ${ }^{4}$ Strategic Improvement Department, UCSF Health, San Francisco, CA; ${ }^{5}$ Department of Epidemiology and Biostatistics, University of \\ California, San Francisco; ${ }^{6}$ San Francisco Veterans Affairs Medical Center, California; ${ }^{7}$ Dean's Office, Dell Medical School, The University of Texas \\ at Austin, Texas.
}

We describe a program called "Caring Wisely" ${ }^{\circledR}$, developed by the University of California, San Francisco's (UCSF), Center for Healthcare Value, to increase the value of services provided at UCSF Health. The overarching goal of the Caring Wisely program is to catalyze and advance delivery system redesign and innovations that reduce costs, enhance healthcare quality, and improve health outcomes. The program is designed to engage frontline clinicians and staff-aided by experienced implementation scientists - to develop and implement interventions specifically designed to address overuse, underuse, or misuse of services. Financial savings of the program are intended to cover the program costs. The theoretical underpinnings for the design of the Caring Wisely ${ }^{\circledR}$ program emphasize the importance of stakeholder engagement, behavior change theory, market (target audience) segmentation, and process measurement and feedback. The Caring Wisely ${ }^{\circledR}$ program provides an institutional model for using crowdsourcing to identify "hot spot" areas of low-value care, inefficiency and waste, and for implementing robust interventions to address these areas.

Designed and launched by the UCSF Center for Healthcare Value in 2013, the annual Caring Wisely ${ }^{\circledR}$ program identifies projects that meet the following criteria: (1) potential to measurably reduce UCSF Health's costs of care without transferring costs to patients, insurers, or other providers; (2) plan for insuring that health outcomes are maintained or improved; (3) envision disseminating the intervention within and beyond
UCSF; and (4) demonstrate commitment and engagement of clinical leadership and frontline staff.

Caring Wisely ${ }^{\circledR}$ consists of 3 stages: (1) the Ideas Contest -an open call to all faculty, staff, and trainees to crowdsource the best ideas for identifying areas of waste; (2) the Request for Proposals stage; and (3) the Project Implementation stage, during which project and implementation science teams meet regularly to develop an implementation strategy for each of three projects with the first test of change occurring within 3-6 months. Project specific budgets are limited to $\$ 50,000$, and program administration costs approximately $\$ 150,000$ per year, for a total program budget of about $\$ 300,000$ per year.

Since 2013, three Caring Wisely ${ }^{\circledR}$ program annual cycles have been completed, encompassing 9 specific projects. The projects have been led by a variety of individuals including physicians, nurses, pharmacists, administrators, and residents, and topics have ranged from reducing overutilization of tests, supplies, and treatments to improving patient throughput in the perioperative period and reducing length of stay. Estimated cumulative savings to date from the Caring Wisely ${ }^{\circledR}$ program have exceeded $\$ 4$ million. We conclude that a program that empowers frontline project teams to work on crowd-sourced ideas with institutional leadership support and implementation science coaching is an effective strategy for reducing in-patient healthcare costs while maintaining high quality care. Journal of Hospital Medicine 2017;12:662-667. (C) 2017 Society of Hospital Medicine
Strategies are needed to empower frontline clinicians to work with organizational leadership to reduce healthcare costs and improve high-value care. Caring Wisely ${ }^{\circledR}$ is a program developed by the University of California, San Francisco's (UCSF) Center for Healthcare Value (CHV), aimed at engaging frontline clinicians and staff, connecting them with implementation experts, and supporting the development of targeted interventions to improve value. Financial savings from the program more than cover program costs.

\footnotetext{
*Address for correspondence and reprint requests: Ralph Gonzales, MD, MSPH, 350 Parnassus Avenue, Suite 500, San Francisco, CA 94117, phone: 415-514-6457; 415-502-2241; Ralph.Gonzales@ucsf.edu

Received: August 11, 2016; Revised: January 30, 2017;

Accepted: February 6, 2017
}

2017 Society of Hospital Medicine DOI 10.12788/jhm.2786
Caring Wisely ${ }^{\circledR}$ provides an institutional model for implementing robust interventions to address areas of low-value care.

Launched in 2013, the annual Caring Wisely ${ }^{\circledR}$ program consists of 3 stages for identifying projects that meet the following criteria:

- Potential to measurably reduce UCSF Health's costs of care without transferring costs to patients, insurers, or other providers

- Plan for ensuring that health outcomes are maintained or improved

- Envision disseminating the intervention within and beyond UCSF

- Demonstrate commitment and engagement of clinical leadership and frontline staff.

The first stage is the Ideas Contest, a UCSF Health-wide 
TABLE 1. Key implementation science principles addressed by specific Caring Wisely ${ }^{\circledR}$ program components.

\begin{tabular}{|c|c|}
\hline Key Program Components & Key Purpose \\
\hline Requests for Proposals & $\begin{array}{l}\text {-confirm the opportunity gap, and the cost savings expectations } \\
\text {-stakeholder input and engagement }\end{array}$ \\
\hline Caring Wisely Steering (Executive) Committee & -ongoing, executive leader support for removing barriers \& supporting critical new work \\
\hline Launch Event and Media Campaign & $\begin{array}{l}\text {-awareness and engagement } \\
\text {-social norms/social ecology }\end{array}$ \\
\hline Data analyst & $\begin{array}{l}\text {-measurement and feedback, which is critical for confirming care gaps, cost-saving opportunities, and guiding rapic } \\
\text { cycle improvements }\end{array}$ \\
\hline $\begin{array}{l}\text { Implementation scientist(s)... including behavioral/social scientists, economists, } \\
\text { systems engineers, etc, as needed. }\end{array}$ & $\begin{array}{l}\text {-help identify appropriate conceptual framework(s) for embedding theory into intervention design; build logic model } \\
\text {-design process evaluation plan to inform rapid-cycle improvements } \\
\text {-interpret findings from rapid-cycle feedback and guide adaptation }\end{array}$ \\
\hline Data scientist & -apply data visualization techniques to catalyze behavior change \\
\hline
\end{tabular}

call (to learn more about UCSF Health: https://www.ucsf. edu/sites/default/files/052516_About_UCSF.pdf) to identify areas that may be targeted to reduce unnecessary services, inefficiencies, and healthcare costs. We use a crowdsourcing platform-Open Proposals-to solicit the best ideas from frontline clinicians and staff. ${ }^{1}$ Open Proposals is a secure, web-based platform for transparent and collaborative proposal development that displays threads of comments, responses, and revisions, and allows submissions to be "liked." Open Proposals is managed by the UCSF Clinical and Translational Science Institute, funded by the National Center for Advancing Translational Sciences (Grant Number UL1 TR000004) at the National Institutes of Health. Using institutional e-mail lists for faculty, staff and residents, as well as described at monthly managers and directors meetings, the Ideas Contest is announced each year by the Chief Medical Officer and the CHV leadership. The Caring Wise$1 y^{\circledast}$ Executive Steering Committee, which consists of CHV and senior UCSF Health system leaders, selects the top 5-10 ideas based on the above criteria. Each winning idea receives a $\$ 100$ gift certificate for a popular restaurant in San Francisco, and the list of winners is announced to the entire UCSF community.

The second stage is the Request for Proposals. The Caring Wisely ${ }^{\circledR}$ program solicits proposals that outline implementation plans to target specific areas identified through the Ideas
Contest. Finalists from the Ideas Contest are encouraged to submit proposals that address the problem they identified, but anyone affiliated with UCSF Health may submit a proposal on a winning idea. There is an approximately 4-week open submission period during which applicants submit brief 2-page proposals on the Open Proposal platform. This is followed by a period of optimization that leverages the social media aspect of the Open Proposals platform in which the UCSF Health community asks clarifying questions, make suggestions, and modifications can be made to the proposals. All submissions receive written feedback from at least one Steering Committee member. In addition, the Caring Wisely ${ }^{\oplus}$ Director directly invites relevant UCSF colleagues, administrators, or program leaders to comment on proposals and make suggestions for improvement. Plans for assessing financial and health care delivery impacts are developed in collaboration with the UCSF Health Finance department. UCSF Health managers and leaders who are stakeholders in project proposal areas are consulted to provide input and finalize proposal plans, including the identification of existing personnel who can support and drive the project forward. Proposers use this feedback to revise their applications throughout this stage.

The third stage is Project Implementation. The Caring Wisely ${ }^{\circledR}$ Executive Steering Committee selects up to 3 winners from the submitted proposals. Using the program crite- 
TABLE 2: A Structured Approach to Designing Interventions to Reduce Overuse of Healthcare Services

\begin{tabular}{|c|c|c|c|c|}
\hline & PLAN & DO & STUDY & ACT \\
\hline \multirow{5}{*}{$\begin{array}{l}\text { Key } \\
\text { Program } \\
\text { Activities }\end{array}$} & & $\begin{array}{l}\text { Learn from previous efforts to change target } \\
\text { behavior }\end{array}$ & \multirow{5}{*}{$\begin{array}{l}\text { Identify key informants from frontline } \\
\text { Measure intervention delivery and reach } \\
\text { Employ strategy for real-time monitoring of } \\
\text { target behavior }\end{array}$} & \multirow{5}{*}{$\begin{array}{l}\text { Feedback process and impact evaluation } \\
\text { to key stakeholders. } \\
\text { Engage stakeholders on sustainability plan. }\end{array}$} \\
\hline & $D$ & & & \\
\hline & Establish behavior change target(s) & $\begin{array}{l}\text { Pllot test intervention components with key } \\
\text { stakeholders }\end{array}$ & & \\
\hline & & $\begin{array}{l}\text { Create community awareness and } \\
\text { excitement }\end{array}$ & & \\
\hline & & Identify key champions & & \\
\hline \multirow{4}{*}{$\begin{array}{l}\text { Intervention } \\
\text { Design } \\
\text { Activities }\end{array}$} & Understand the target behavior ${ }^{\star 3}$ & Intervene on the target behavior ${ }^{3}$ & $\begin{array}{l}\text { Conduct process and impact evalu- } \\
\text { ation of intervention }\end{array}$ & $\begin{array}{l}\text { Revise design and implementation } \\
\text { strategy }\end{array}$ \\
\hline & $\begin{array}{l}\text { 1. What knowledge, attitudes, and social } \\
\text { norms predispose to the target behavior? }\end{array}$ & $\begin{array}{l}\text { 1. Incorporate component(s) that address } \\
\text { predisposing factors. Tailor to different } \\
\text { audiences. }\end{array}$ & $\begin{array}{l}\text { 1. Evaluate impact of intervention on predis- } \\
\text { posing, enabling and reinforcing factors. }\end{array}$ & $\begin{array}{l}\text { 1. Based on process evaluation, do you modify } \\
\text { strategy and/or which factors to target? }\end{array}$ \\
\hline & $\begin{array}{l}\text { 2. What factors enable the target behavior? } \\
\text { What factors impede the desired } \\
\text { behavior? }\end{array}$ & $\begin{array}{l}\text { 2. Incorporate component(s) that make the } \\
\text { desired behavior "easy" by redesigning } \\
\text { work flows or eliminating barriers. }\end{array}$ & $\begin{array}{l}\text { 2. Measure impact of intervention on target } \\
\text { behavior(s). }\end{array}$ & $\begin{array}{l}\text { 2. Does impact evaluation support the logic } \\
\text { model? }\end{array}$ \\
\hline & $\begin{array}{l}\text { 3. What factors reinforce the target } \\
\text { behavior? }{ }^{\star *}\end{array}$ & $\begin{array}{l}\text { 3. Incorporate component(s) that reward/ } \\
\text { reinforce the desired behavior. }\end{array}$ & $\begin{array}{l}\text { 3. Measure impact of intervention on } \\
\text { overuse gap. }\end{array}$ & $\begin{array}{l}\text { 3. Have new barriers emerged that were not } \\
\text { obvious initially? }\end{array}$ \\
\hline
\end{tabular}

*Perform this through literature review, as well as local institution exploration with relevant stakeholders

* What "good" things happen to the individual when they perform the target behavior? What "bad" things happen to the individual if/when they stop performing the target behavior

ria above, each project is scored independently, discussed in committee, and rescored to identify the top proposals. Each selected project receives a maximum budget of $\$ 50,000$ that can be used for project materials, activities, and salary support for project leaders or staff. In addition to funding, each project team receives input from the implementation science team to co-develop and implement the intervention with a goal of creating a first-test-of-change within 3-6 months. A key feature of Caring Wisely ${ }^{\circledR}$ is the partnership between project teams and the Caring Wisely ${ }^{\circledR}$ implementation team, which includes a director, program manager, data analysts, and implementation scientists (Table 1).

The $\$ 150,000$ administrative budget for the Caring Wise$1 y^{\circledR}$ program provides $20 \%$ support of the medical director, $50 \%$ support of a program manager/analyst, and $10 \%$ support of an implementation scientist. Approximately 5\% support is donated from additional senior implementation scientists and various UCSF Health experts based on project needs. To make most efficient use of the Caring Wisely ${ }^{\circledR}$ program staff time with the project teams, there is a weekly 60-90 minute works-in-progress session attended by all 3 teams with a rotating schedule for lead presenter during the first 6 months; these meetings occur every 2-3 weeks during the second 6 months. Caring Wisely ${ }^{\oplus}$ program staff and the implementation scientist are also available for 1:1 meetings as needed. The Caring Wisely ${ }^{\circledR}$ Executive Steering Committee is not paid and meets for 90 minutes quarterly. Custom reports and modifications of the electronic health record are provided by the UCSF Health clinical informatics department as part of their operating budget.

The collaboration between the project teams and the implementation science team is guided by the Consolidat- ed Framework for Implementation Research $(\text { CFIR })^{2}$ and PRECEDE-PROCEED model-a logic model and evaluation tool that is based on a composite of individual behavior change theory and social ecology. ${ }^{3}$ Table 2 illustrates how we weave PRECEDE-PROCEED and Plan-Do-Study-Act frameworks into project design and strategy. Each funded team is required to submit an end-of-year progress report.

Cost and cost savings estimates were based on administrative financial data obtained through the assistance of the Decision Support Services unit of the Finance Department of UCSF Health. All costs reflect direct institutional costs, rather than charges. For some projects, costs are directly available through computerized dashboards that provide year-to-year comparisons of specific costs of materials, supplies, and services (eg, blood transfusion reduction, surgical supplies project, OR efficiency program). This same dashboard also allows calculation of CMI-adjusted direct costs of hospital care by service line, as used in the perioperative pathways program evaluation. In other cases, the Decision Support Services and/or Caring Wisely ${ }^{\circledR}$ program manager created custom cost reports based on the key performance indicator (eg, nebulizer therapy costs consist of medication costs plus respiratory therapist time; CT scan utilization for suspected pulmonary embolus in emergency department; and antimicrobial utilization for suspected neonatal sepsis).

Ongoing monitoring and sustainability of Caring Wisely ${ }^{\circledR}$ projects is supported by the Caring Wisely ${ }^{\circledR}$ program leaders. Monitoring of ongoing cost savings is based on automated service-line level dashboards related to cost, utilization, and quality outcomes with quarterly updates provided to the Caring Wisely ${ }^{\circledR}$ Steering Committee. Depending on the project or program, appropriate UCSF Health senior leaders 
TABLE 3. Summary of Caring Wisely ${ }^{\circledR}$ Projects, Fiscal Year 2014 - Fiscal Year 2016

\begin{tabular}{|c|c|c|c|c|c|}
\hline Title & Project Objective & $\begin{array}{l}\text { Principle Intervention } \\
\text { Components }\end{array}$ & Target Patient Population & Primary Unit of Analysis & Balancing Metrics \\
\hline \multicolumn{6}{|c|}{ Year 1: Fiscal Year 2014} \\
\hline $\begin{array}{l}\text { Blood Transfusion } \\
\text { Reduction }\end{array}$ & $\begin{array}{l}\text { Reduce excess red blood cell } \\
\text { transfusion }\end{array}$ & $\begin{array}{l}\text { Guideline education; } \\
\text { Media campaign; } \\
\text { EMR decision support }\end{array}$ & $\begin{array}{l}\text { Orthopedic Surgery/Hospital } \\
\text { Medicine } \rightarrow \text { all hospital }\end{array}$ & $\begin{array}{l}\text { Packed red blood cell units per hospital } \\
\text { discharge }\end{array}$ & Return to OR \\
\hline $\begin{array}{l}\text { Nebulizer-MDI } \\
\text { Transition }\end{array}$ & $\begin{array}{l}\text { Promote transition to MDI within } \\
24 \text { hours of nebulizer therapy }\end{array}$ & $\begin{array}{l}\text { Education; } \\
\text { Media campaign }\end{array}$ & Hospital Medicine & $\begin{array}{l}\text { Nebulizer treatments per hospital } \\
\text { medicine discharge }\end{array}$ & $\begin{array}{l}\text { Length of Stay } \\
\text { Readmission }\end{array}$ \\
\hline IV-to-PO Switch & $\begin{array}{l}\text { Reduce IV meds in patients able } \\
\text { to take PO meds }\end{array}$ & $\begin{array}{c}\text { EMR audit tool with PharmD } \\
\text { outreach }\end{array}$ & $\begin{array}{l}\text { Patients receiving IV medications } \\
\text { approved for interchange }\end{array}$ & $\begin{array}{l}\text { Medication cost difference for accepted } \\
\text { conversions }\end{array}$ & $\begin{array}{l}\text { Return to IV therapy } \\
\text { Length of Stay }\end{array}$ \\
\hline \multicolumn{6}{|c|}{ Year 2: Fiscal Year 2015} \\
\hline $\begin{array}{l}\text { Surgical Supply Cost } \\
\text { Reduction }\end{array}$ & $\begin{array}{l}\text { Substitute lower cost surgical } \\
\text { supplies when appropriate }\end{array}$ & $\begin{array}{l}\text { Audit/feedback/profiles; } \\
\text { Financial incentive }\end{array}$ & $\begin{array}{c}\text { Neurosurgery, Orthopedic Surgery, } \\
\text { OHNS }\end{array}$ & $\begin{array}{l}\text { Operating room supply costs per } \\
\text { department }\end{array}$ & $\begin{array}{l}\text { Length of Stay } \\
\text { Readmission }\end{array}$ \\
\hline Perioperative Efficienc & $\begin{array}{l}\text { Improve patient flow and efficien- } \\
\text { cy in perioperative period }\end{array}$ & $\begin{array}{l}\text { Community engagement; } \\
\text { Process mapping; } \\
\text { Audit/feedback/profiles }\end{array}$ & $\begin{array}{l}\text { All surgical services at Mission } \\
\text { Bay hospital }\end{array}$ & $\begin{array}{l}\text { Average operating room turnover time } \\
\text { per month }\end{array}$ & Return to $\mathrm{OR}$ \\
\hline $\begin{array}{l}\text { CT for PE Risk } \\
\text { Prediction }\end{array}$ & $\begin{array}{l}\text { Increase guideline-concordant } \\
\text { use of CT for suspected PE }\end{array}$ & $\begin{array}{l}\text { Guideline education; } \\
\text { EMR prediction tool }\end{array}$ & $\begin{array}{l}\text { Parnassus Hospital Emergency } \\
\text { Department }\end{array}$ & $\begin{array}{l}\text { CT scan per eligible emergency depart- } \\
\text { ment patient }\end{array}$ & $\begin{array}{l}\text { Length of ED Stay } \\
\text { Return to ED for pulmonary embolus }\end{array}$ \\
\hline \multicolumn{6}{|c|}{ Year 3: Fiscal Year 2016} \\
\hline ERAS Pathways & $\begin{array}{l}\text { Enhance patient recovery and } \\
\text { experience after surgery }\end{array}$ & $\begin{array}{c}\text { Education; } \\
\text { Audit/feedback/profiles }\end{array}$ & $\begin{array}{c}\text { Colorectal Oncology and Gyneco- } \\
\text { logic Oncology Services at Mission } \\
\text { Bay Hospital }\end{array}$ & $\begin{array}{l}\text { CMI-adjusted direct cost per hospital } \\
\text { discharge }\end{array}$ & $\begin{array}{c}\text { Return to OR } \\
\text { Length of Stay } \\
\text { Patient Experience }\end{array}$ \\
\hline $\begin{array}{l}\text { Neonatal Sepsis Risk } \\
\text { Prediction }\end{array}$ & $\begin{array}{l}\text { Reduce prophylactic antibiotic } \\
\text { use for babies at risk for sepsis }\end{array}$ & $\begin{array}{l}\text { Education; } \\
\text { EMR prediction tool }\end{array}$ & Newborns at Mission Bay Hospital & $\begin{array}{l}\text { Antibiotic utilization per } 100 \text { eligible } \\
\text { newborns }\end{array}$ & $\begin{array}{l}\text { Return to NICU } \\
\text { Length of Stay }\end{array}$ \\
\hline \multicolumn{2}{|c|}{$\begin{array}{l}\text { Post-Operative Debrief Identify and fix safety and quality } \\
\text { issues }\end{array}$} & $\begin{array}{l}\text { Education; } \\
\text { EMR tool }\end{array}$ & All surgical services at all hospitals & Surgical safety climate score & OR turnover time \\
\hline
\end{tabular}

determine the level of support within their departments that is required to sustain the program(s). Ongoing monitoring of each program is also included in the strategic deployment visibility room with regular rounding by senior health system executives.

Since 2013, there have been 3 complete Caring Wisely ${ }^{\circledR}$ cycles. The Ideas Contest generated more than 75 ideas in each of the past 3 cycles, ranging from eliminating redundant laboratory or radiological studies to reducing linen and food waste. We received between 13-20 full proposals in each of the request for proposal stages, and 9 projects have been implemented, 3 in each year. Funded projects have been led by a variety of individuals including physicians, nurses, pharmacists, administrators and residents, and topics have ranged from reducing overutilization of tests, supplies and treatments, to improving patient throughput during the perioperative period (Table 3 ). Estimated cumulative savings to date from Caring Wisely ${ }^{\circledR}$ projects has exceeded $\$ 4$ million, based on the four projects shown in Table 4. The IV-to-PO switch program and the neonatal sepsis risk prediction project (Table 3 ) have been successful in reducing unnecessary utilization, but cost and savings estimates are not yet finalized. Three funded projects were equivocal in cost savings but were successful in their primary aims: (1) increasing the appropriateness of CT scan ordering for suspected pulmonary embolus; (2) shortening operating room turnover times; and (3) implementing a postoperative debrief program for the systematic documentation of safety events, waste, and inefficiencies related to surgery.

We developed an innovative program that reduces hospital costs through crowdsourcing of ideas from frontline clinicians and staff, and by connecting these ideas to project and implementation science teams. At a time when healthcare costs have reached unsustainable levels, the Caring Wisely ${ }^{\circledR}$ program provides a process for healthcare personnel to make a positive impact on healthcare costs in areas under their direct control. Through the Open Proposals platform, we have tapped a growing desire among frontline providers to reduce medical waste.

A key criterion for the Caring Wisely ${ }^{\circledR}$ program is to propose changes that reduce cost without adversely affect healthcare quality or outcomes. While this is an important 


\section{TABLE 4 Cost Savings and Balancing Metrics for Selected Caring Wisely ${ }^{\circledR}$ Projects}

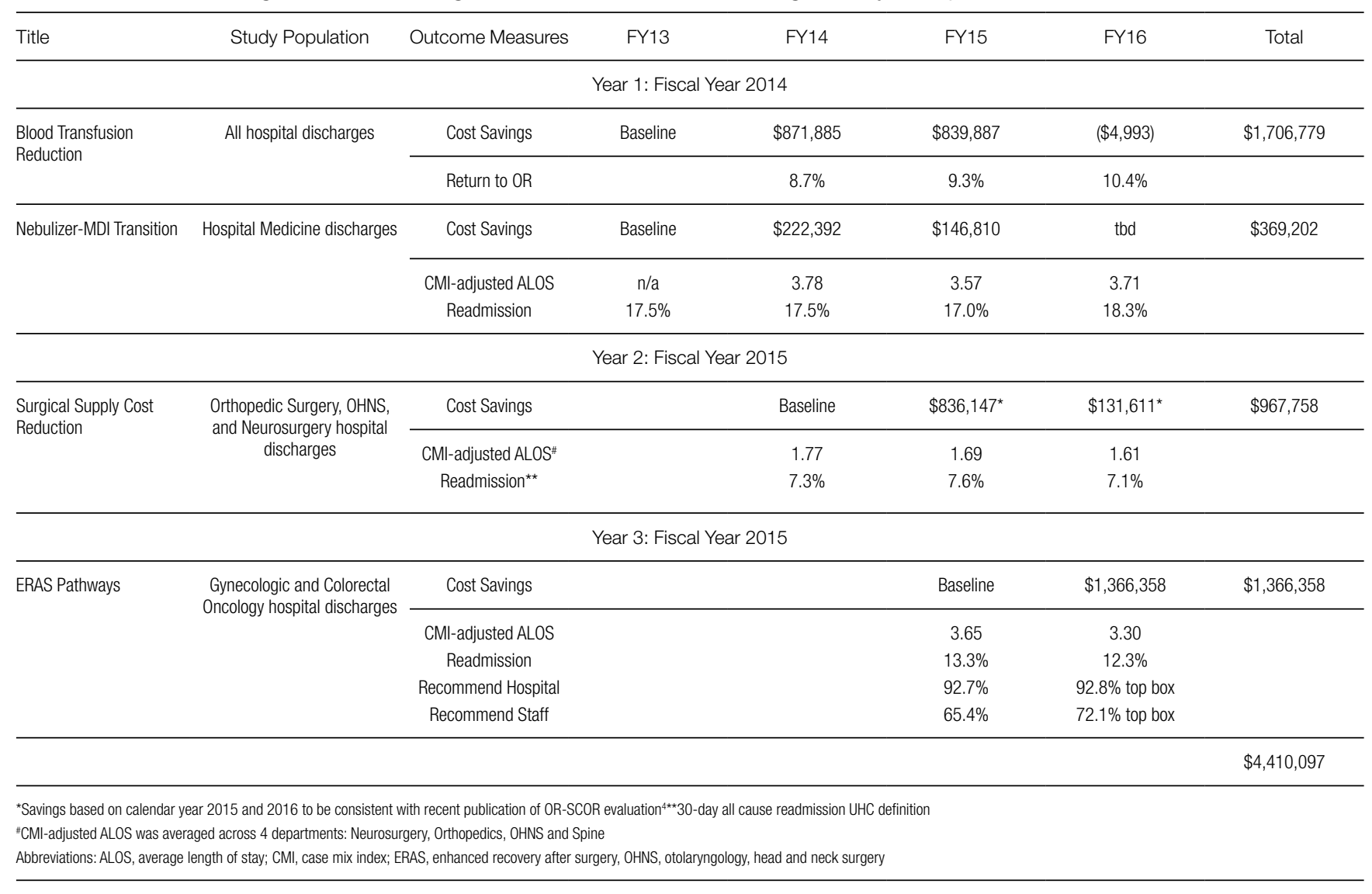

consideration in selecting projects, there is limited power to detect many of the most clinically relevant outcomes. We find this acceptable because many of the sponsored Caring Wisely ${ }^{\circledR}$ project goals were to increase compliance with evidence-based practice guidelines and reduce harms associated with unnecessary treatments (eg, blood transfusion, nebulizer therapy, CT scan, antimicrobial therapy). Selected balancing metrics for each project are reported by established quality and safety programs at UCSF Health, but we acknowledge that many factors that can affect these clinical outcomes are not related to the cost-reduction intervention and are not possible to control outside of a clinical research study. Therefore, any response to changes in these outcome and balancing measures requires further analysis beyond the Caring Wisely ${ }^{\circledR}$ project alone.

We believe one of the key factors in the success of the Caring Wisely ${ }^{\circledR}$ program is the application of implementation science principles to the intervention design strategies ( Table 1). These principles included stakeholder engagement, behavior change theory, market (target audience) segmentation, and process measurement and feedback. Because we are conducting this program in an academic health center, resident and fellow education and engagement are also critical to success. In each project, we utilize the PRECEDE model as a guide to ensure that each intervention design includes complementary elements of effective behavior change, intended to increase awareness and motivation to change, to make change "easy," and to reinforce change (Table 2). ${ }^{3}$

The Caring Wisely ${ }^{\circledR}$ program-itself a multifaceted intervention-embodies the same PRECEDE dimensions we apply to each specific project. The Ideas Contest serves as a tool for increasing awareness, attitudes, and motivation across the clinical enterprise for reducing healthcare costs. The support provided to the project teams by the Caring Wisely ${ }^{\circledR}$ program is an enabling factor that makes it "easier" for frontline teams to design and implement interventions with a greater likelihood of achieving early success. Timely measurement and feedback of results to the hospital leadership and broadcasting to the larger community reinforces the support of the program at both the leadership and frontline levels.

Collaboration between project teams and the Caring Wisely ${ }^{\circledR}$ program also provides frontline clinicians and staff with practical experience and lessons that they can apply to future improvement work. Project teams learn implementation science principles such as constructing a pragmatic theoretical framework to guide implementation design using CFIR model. ${ }^{2}$ Incorporating multiple, rapid-cycle tests of change allows teams to modify and adapt final interventions as they learn how the target audience and environ- 
ment responds to specific intervention components. Access to real-time, actionable data and a data analyst is essential to rapid cycle adaptation that allows teams to focus on specific units or providers. We also find that cross-fertilization between project teams working in different areas helps to share resources and minimize duplication of efforts from the clinical and staff champions. Partnering with UCSF Health system leaders at every phase of project development-from proposal selection, development, and final evaluation of results-enhances sustainable transition of successful projects into clinical operations.

The costs and coordination for the first cycle of Caring Wisely ${ }^{\circledR}$ were supported by the UCSF Center for Healthcare Value. Upon completion of the evaluation of the first cycle, UCSF Health agreed to fund the program going forward, with the expectation that Caring Wisely would continue to achieve direct cost-savings for the organization. The Caring Wisely team provides a final report each year detailing the impact of each project on utilization and associated costs. Currently, program costs are approximately $\$ 150,000$ for the Caring Wisely program leaders, staff, and other resources, and $\$ 50,000$ for each of 3 projects for a total program cost of $\$ 300,000$ per year. Projects included in the first three cycles have already saved more than $\$ 4$ million, representing a strong return on investment. This program could be a model for other academic health centers to engage frontline clinicians and staff in addressing healthcare costs, and lends itself to being scaled-up into a multi-system collaborative.

\section{LIST OF ABBREVIATIONS}

UCSF-University of California, San Francisco; PRECEDE—Predisposing, Reinforcing, and Enabling Constructs in Educational Diagnosis and Evaluation; PROCEED—Policy, Regulatory and Organizational Constructs in Educational and Environmental Development

\section{Acknowledgments}

Other participants in blood transfusion reduction project (D. Johnson, K. Curcione); IV-to-PO Switch (C. Tsourounis, A. Pollock); Surgical Supply Cost Reduction (C. Zygourakis); Perioperative Efficiency (L. Hampson); CT for PE Risk Prediction (E. Weber); ERAS Pathways (L. Chen); Neonatal Sepsis Risk Prediction (T. Newman); Post-Operative Debrief (S. Imershein). Caring Wisely Executive Steering Committee (J. Adler, S. Antrum, A Auerbach, J. Bennan, M. Blum, C. Ritchie, C. Tsourounis). This Center for Healthcare Value is funded in part by a grant from the Grove Foundation. We appreciate additional review and comments to the manuscript provided by George Sawaya and Adams Dudley.

Disclosures: Christopher Moriates has accepted royalties from McGraw-Hill for textbook, Understanding Value-Based Healthcare. Alvin Rajkomar has received fees as a research adviser from Google, Inc.

\section{REFERENCES}

1. Kahlon M, Yuan L, Gologorskaya O, Johnston SC. Crowdsourcing the CTSA innovation mission. Clin Transl Sci. 2014;7:89-92.

2. Damschroder LJ, Aron DC, Keith RE, Kirsh SR, Alexander JA, Lowery JC. Fostering implementation of health services research findings into practice: a consolidated framework for advancing implementation science. Implement Sci. 2009;4:50.

3. Green LW and Kreuter. Health Program Planning: An Educational and Ecological Approach. $4^{\text {th }}$ Ed. McGraw-Hill. New York, NY. 2005.

4. Zygourakis CC, Valencia V, Moriates C et al. Association between surgeon scorecard use and operating room costs. JAMA Surg. 2016 Dec 7. doi: 10.1001/jamasurg.2016.4674. [Epub ahead of print] 